\title{
Dermatoglyphics in Dentistry: An Insight
}

NS Priya, P Sharada, N Chaitanya Babu, HC Girish

\section{ABSTRACT}

Fingerprint analysis for personal identification is well known, as it is unique to all individuals and remains unchanged over a life time. Now it is getting identified as a useful tool in understanding the basic questions in genetics and is emerging as an independent field in dentistry as dermatoglyphics.

Dermatoglyphics are the dermal ridge configurations on the digits, palms and soles. Significant dermatoglyphics investigations have been carried for chromosomal disorders like Down syndrome, Turner syndrome, etc.

The history, embryogenesis and topology of dermatoglyphics with emphasis on the various studies involving dermatoglyphics has been focused in this review.

Keywords: Dermatoglyphics, Fingerprints, Ridge count, Palmar patterns.

How to cite this article: Priya NS, Sharada P, Chaitanya Babu N, Girish HC. Dermatoglyphics in Dentistry: An Insight. World J Dent 2013;4(2):144-147.

\section{Source of support: Nil}

Conflict of interest: None declared

\section{INTRODUCTION}

Dermatoglyphics is the science and art of surface markings of the skin especially feet and hands (Derma: Skin, Glyph: Carving).

Cummins and Midlo (1926) were the first to coin the term dermatoglyphics. ${ }^{1}$ It is the dermal ridge configuration of digits, palms and soles. The ridge formation begins to develop about the 13th week of prenatal life and pattern formation is completed in the 19th week. ${ }^{1}$

Fingerprints are unique to all individuals and remain unchanged over the lifetime. Multiple genes determine fingerprint configurations and the study of fingerprints reveal vital genetic and medical information about an individual. Dermatoglyphic studies have been carried out on leukemia, breast cancer, pulmonary tuberculosis, syndromes, etc.

Dermatoglyphics in dentistry is proving to be a reliable tool for preliminary investigations of oral pathosis with suspected genetic basis. Significant dermatoglyphic studies have been carried out in conditions like Down syndrome, dental caries, oral clefts, oral submucous fibrosis.

\section{History of Dermatoglyphics}

- William Herschel (1858) was the first to experiment with fingerprints in India. ${ }^{2}$

- Sir Francis Galton (1892) with his extensive research demonstrated the hereditary significance of fingerprints and biological variations of different racial groups. ${ }^{3}$
- Sir Edward Henry (1893) published the book 'The classification and uses of fingerprints,' commencing a modern era of fingerprint identification. ${ }^{4}$

- Cummins and Midlo (1926) coined the term dermatoglyphics. ${ }^{4}$

- Penrose LS (1945) conducted dermatoglyphic investigation in Down's syndrome and other congenital disorders. ${ }^{5}$

- Schaumann and Alter's (1976) published the book 'Dermatoglyphics in medical disorders. ${ }^{1}$

- Dermatoglyphics today: The current state of medical dermatoglyphics is such that the diagnosis of some diseases can now be done on the basis of dermatoglyphics alone. Currently, several researchers claim very high degree of accuracy in their prognostic ability from the hand features.

\section{Embryogenesis of Dermatoglyphics}

The dermal ridge configurations are a direct consequence of the surface topography of the fetal hand during the dermal ridge development between 13th and 19th weeks of prenatal life. $^{6}$

Stages are:

1. Early limb development (4-6 week)

2. Pad appearance (61/2-8 week)

3. Pad regression (10-12 week)

4. Ridge formation (13th week)

5. Definite pattern (19th week)

Dermal ridge configurations are the immediate result of physical and topographic growth forces affecting volar skin which is predisposed in a polygenic manner to form parallel dermal ridges. Ridge patterning is directly determined by genes, but is the indirect consequence of the total form of the hand at the time ridges are developing. ${ }^{6}$

Penrose (1968) ${ }^{7}$ suggested that ridges which are aligned at right angles to compression forces, take the shortest routes on the embryonic surfaces and the abnormal configurations are the result of alterations in the fluid balance at an early embryonic stage.

Hirsch et al (1973) ${ }^{8}$ summarized that the arrangement of blood vessels and nerve pairs under the smooth epidermis exists shortly before glandular folds and speculated that the folds were induced by the blood vessel-nerve pairs. Neuroepithelium plays an important role in the development of patterns. 
Pattern configurations: It can be divided into palmar and fingertip patterns: Table 1.

Palm is divided into several anatomical areas like thenar area, four interdigital areas and hypothenar area. Thenar area does not show any pattern ${ }^{1}$ (Fig. 1).

The three major palmar creases are seen.

Distal crease (DC): It originates from the lateral side of the palm and ends in between the pointing finger and the middle finger.

Proximal crease (PC): It originates from the hypothenar area and ends in between the thumb and pointing finger.

Table 1: Types of palmar and fingertip patterns

\begin{tabular}{ll}
\hline Palmar patterns & Fingertip patterns \\
\hline - Thenar area (Th or $\left.\mathrm{I}_{1}\right)$ & - Arches \\
- Hypothenar area $(\mathrm{Hy})$ & - Loops \\
- Interdigital areas $\left(\mathrm{I}_{2}, \mathrm{I}_{3}, \mathrm{I}_{4}\right)$ & - Whorls \\
- Palmar creases $(\mathrm{DC}, \mathrm{PC}$ and $\mathrm{TC})$ & \\
- Atd angle & \\
\hline
\end{tabular}

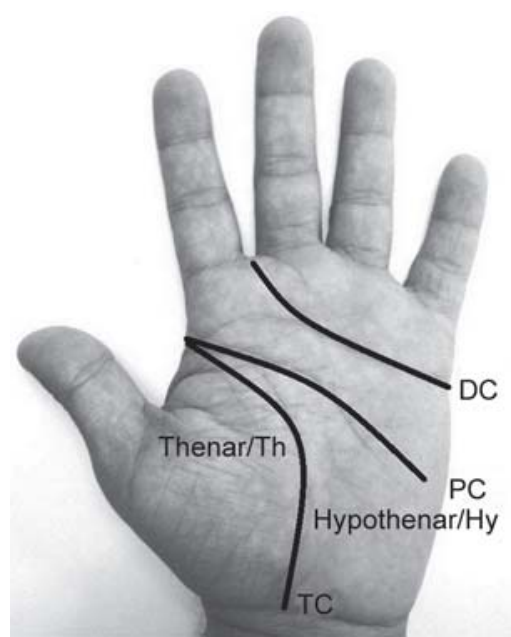

Fig. 1: Pattern configurations

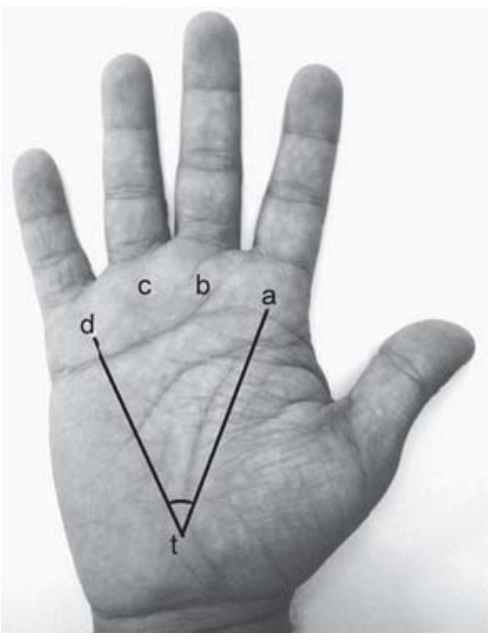

Fig. 2: Atd angle
Thenar crease (TC): It originates from the base of the palm and ends in between the thumb and pointing finger, generally fused with PC.

Atd angle: An angle formed by lines drawn from the digital triradius (a) to the axial triradius ( $\mathrm{t}$ ) and from this to digital triradius (d) is called atd angle. The more distal the position of $t$, the larger is the atd angle ${ }^{1}$ (Fig. 2).

Triradius: It is formed by the confluence of three ridge systems. The geometric centre of triradius is designated as a triradial point. It is the meeting point of three ridges that form angles of approximately $120^{\circ}$ with one another. ${ }^{1}$

\section{Fingertip Patterns}

Galton (1892) divided the fingertip patterns into three groups: ${ }^{1}$

Arches-Simple arch and tented arch

Loops-Ulnar loop and radial loop

Whorls: Central pocket whorl and simple whorl arches: It is the simplest pattern found on fingertips. Simple arch is composed of ridges that cross the fingertip from one side to the other and has no triradius. Tented arch is composed of ridges that meet at a point so that their smooth sweep is interrupted and has a central triradius.

Loops: It is the most common pattern with series of ridges entering the pattern area on one side of the digit and leaving the area on the same side. If the ridge opens on the ulnar side, it is called ulnar loop and if it opens on toward the radial side, it is called radial loop.
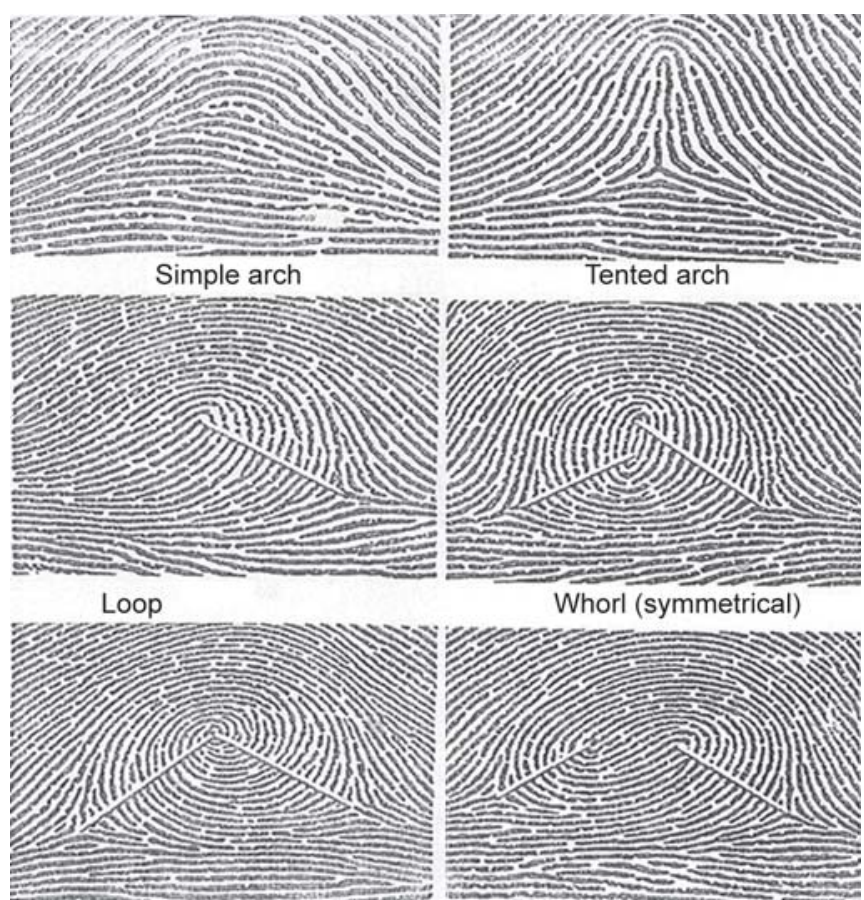

Fig. 3: Finger tip patterns 
Whorl: It is any ridge configuration with two or more triradii and ridges actually encircle a core. A central pocket whorl is a pattern containing loop within which a smaller whorl is located $^{1}$ (Fig. 3).

Methods of printing: The methods used for palm printing is inexpensive and rapid.

Ink method: One of the most widely used method. The necessary equipment consists of printer's ink, a roller, a glass or metal inking slab, a sponge rubber and good quality paper preferably with a slightly glazed surface. ${ }^{9}$

Faurot inkless method: Commercially available patented solution and specially treated sensitized paper is used in this method. ${ }^{9}$

Transparent adhesive tape method: In this method, the print is produced by applying a dry coloring pigment to the skin, and lifting it off with the transparent adhesive tape. The coloring agent may be colored chalk, dust, India ink, standard ink, carbon paper, graphite stick or powdered graphite, common oil pastel crayon, etc. Advantage is prints are clear and not smudged and can be preserved for an indefinite period of time. ${ }^{1}$

Photographic method: It is based on the principles of total internal reflection which occurs when an object is pressed against a prism. The magnified image is photographed by a Polaroid camera. ${ }^{5}$

Special methods: It allows the study of the correlation between the epidermal patterns and the underlying bone structures (radiodermatography), study of sweat pores (hygrophotography), or study of the spatial shape of the ridged skin areas, for example in primates (plastic mold method). ${ }^{1}$

In most individuals, other than newborns, the dermal patterning can be observed directly without magnification or with the aid of a simple hand lens and good lighting.

Numerical method: Algorithm of synthesis of images of fingerprints is used and in particular all the possible arrangements of so called minutiae are created. The model allows looking at digital coding of a fingerprint and also enables mathematical cataloguing of minutiae and types of patterns. $^{10}$

Dermatoglyphic studies in dentistry: As dermatoglyphics are genetically controlled characteristics, any deviation in dermatoglyphics features indicates a genetic difference between normal and abnormal. Dermatoglyphics has been considered a window of congenital abnormalities and other conditions.

\section{Down's Syndrome ${ }^{11}$}

- High frequency of simian crease

- Ulnar loops on fingers

- Bilateral

- $\quad$ Radial loop on digit 4 and 5.

\section{Turner's Syndrome ${ }^{11}$}

- Short fifth finger

- $\quad$ Atd $\geq 120$

- $\quad$ Ab ridge count $\geq 105$

- Bilateral hypothenar pattern

- A-line in the thenar crease.

\section{Klinefelter's Syndrome ${ }^{11}$}

- Slight increase in height of the axial triradius in hypothenar pattern

- Decrease in thenar pattern.

\section{Pseudohypoparathyroidism ${ }^{11}$}

- Short broad bands

- High axial triradius

- Increased arch patterns.

\section{Rubinstein-Taybi syndrome ${ }^{11}$}

- Bilateral $\mathrm{I}_{2}$ and $\mathrm{I}_{3}$

- Four or more arches in the fingertips.

\section{Cleft Lip and Cleft Palate ${ }^{12}$}

- Increased triradii count

- Rare patterns on thenar eminence in hands

- Significantly more arches, double loops and ulnar loops

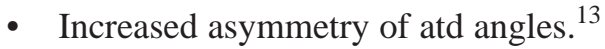

\section{Dental Caries ${ }^{14}$}

- Increased whorl pattern

- Total finger ridge count was higher

- High frequency of arches and radial loops in thenar and interdigital areas

- Atd angle was between 45 and 56 .

\section{Oral Submucous Fibrosis ${ }^{15}$}

- Increase in frequency of arches

- Decrease in frequency of simple whorls

- Increase in pattern frequency in thenar/ $\mathrm{I}_{1}$ area

- Decrease in atd angle.

\section{Limitations of Dermatoglyphics}

- It is difficult for the dermatoglyphics patterns to be diagnostically useful, if the patient has gross malformations of the limbs ${ }^{11}$ 
- There are several disadvantages for using atd angle as a parameter. The most important shortcoming is the size of atd angle that is affected by the amount of spreading of the fingers when the patterns are recorded. The pressure exerted can also affect the atd angle. ${ }^{1}$

- Care must be taken while recording the prints to apply the ink material in adequate amounts. A thin or thick application results in light or dark improper prints.

\section{CONCLUSION}

Fingerprints are known to be unique and unalterable and hence an excellent tool for population studies, personal identification, morphological and genetic research. As the dermatoglyphics are genetically controlled characteristics, any deviation in dermatoglyphics patterns indicates a genetic difference between control group and abnormal population. Though dermatoglyphics are considered an inexact science, has moved from obscurity to acceptability as a diagnostic tool. Extensive research in this field is required in order to determine the validity.

\section{REFERENCES}

1. Schaumann B, Alter M. Dermatoglyphics in medical disorders. New York: Springer Verlag Publishers 1976:27-87.

2. Herschel WJ. Skin furrows of the hand. Nature 1880;23:76.

3. Galton F. Fingerprints. London: MacMillan Publishers 1892:3-5.

4. Cummins H, Midlo C. Fingerprints, palms and soles-An introduction to dermatoglyphics. Philadelphia: Blakiston company 1943:11-15.

5. Penrose LS. Dermatoglyphic topology. Nature 1965;2005: 540-1470.

6. Mulvihill JJ, Smith DW. The genesis of dermatoglyphics. J Pediatr 1969;75:579-89.

7. Penrose LS, Ohara PT. The development of the epidermal ridges. J Med Genet 1973;10:201.

8. Hirsch W, Schweichel JU. Morphological evidence concerning the problem of skin ridge formation. J Ment Defic Res 1973;17:58-72.
9. Miller JR, Giroux J. Dermatoglyphics in pediatric practice. J Pediatr 1969;75:302-12.

10. Jurgensen AP, Kosz D. Fingerprint verification for use in identity verification system. Aalborg University 1993:257-80.

11. Preus M, Fraser F. Dermatoglyphics and syndromes. Amer J Dis Child 1972;24:933-43.

12. Mathew L, Hegde AM, Rai K. Dermatoglyphic peculiarities in children with oral clefts. J Indian Soc Pedod Prev Dent 2005;23:179-82.

13. Adams MS, Niswander JD. Developmental noise and a congenital malformation. Genet Res 1967;10:313.

14. Ahmed RH, Aref MI, Hassan RM, Mohammed NR. Dermatoglyphic study on patients with dental caries who wearing dental fillings and its correlation to apoptosis that induced by using dental fillings. Nature Sci 2010;8:54-57.

15. Veena HS. Cross-sectional study of palmar dermatoglyphics among gutkha chewers with and without oral submucous fibrosis. Karnataka, Bengaluru: Rajiv Gandhi University of Health Sciences, Mar 2006.

\section{ABOUT THE AUTHORS}

\section{NS Priya (Corresponding Author)}

Reader, Department of Oral Pathology, VS Dental College and Hospital, Bengaluru, Karnataka, India, Phone: 08861777706, e-mail: dr_priyans@yahoo.com

\section{P Sharada}

Professor and Head, Department of Oral Pathology, AECS Maaruti College of Dental Sciences and Research, Bengaluru, Karnataka, India

\section{N Chaitanya Babu}

Professor, Department of Oral Pathology, Oxford Dental College and Hospital, Bengaluru, Karnataka, India

\section{HC Girish}

Professor and Head, Department of Oral Pathology, Raja Rajeshwari Dental College and Hospital, Bengaluru, Karnataka, India 